\title{
MEMBANGUN KEMAMPUAN MEMBACA AL-QUR'AN MAHASANTRI MELALUI PEMBELAJARAN AL-QUR'AN DI YPPP. AN-NURIYAH SURABAYA
}

\author{
Alaika M Bagus Kurnia \\ Sekolah Tinggi Ilmu Kesehatan Surabaya \\ E-Mail: alexbagus.1992@gmail.com
}

Mochamad Abdul Ghofur

Institut Pesantren KH Abdul Chalim Mojokerto Indonesia

E-Mail: blueznile85@gmail.com

\begin{tabular}{|c|c|c|}
\hline Received & Revised & Accepted \\
\hline 4 July 2019 & 2 Agustus 2019 & 20 Agustus 2019 \\
\hline
\end{tabular}

\section{THE CONSTRUCTION OF COMPETENCE IN RECITING AL-QURAN MAHASANTRI TRHOUGH AL-QURAN LEARNING IN YPP. AN-NURIYAH SURABAYA}

\begin{abstract}
Surabaya, is a concrete location to be the object of discussion about how the Qur'anic scientific development in it. Because, the public activity is quite high, causing the Qur'an to only be discussed at the level of the clergy or santri. Another concrete proof, in the era of the 90s, was the Al-Qur'an Education Park (TPQ) which had been mushrooming in village corners for a long time, now it is difficult to maintain both management and resources. So that at this time in the 2000s TPQ was said to be very backward because Islamic schools and others both at the elementary and secondary levels had offered tartil learning programs reading Al-Qur'an. In fact, there are also schools that incorporate Qur'anic learning on regular curricula or subjects.Methodologically, this research is qualitative research using the Participatory Action Research approach. This approach is intended to see, hear, and at the same time understand the social symptoms that exist in mahasantri and the surrounding community.From the author's observation directly, it can be seen that the ability of students in YPPP an-Nuriyah does vary. In general, they can be said to be in the medium level and above. With the similarity of sexes, that is, all students
\end{abstract}


in this pesantren are women, the Qur'anic learning for them is easier and more supportive for their reading.

Keywords: Reading, Al-Qur'an, santri.

\begin{abstract}
Abstrak
Surabaya, adalah lokasi konkrit untuk dijadikan objek diskusi tentang bagaimana perkembangan ilmu Al Qur'an di dalamnya. Karena, aktivitas publik cukup tinggi, menyebabkan Alquran hanya didiskusikan di tingkat pendeta atau santri. Bukti nyata lainnya, di era 90-an, adalah Taman Pendidikan Al-Qur'an (TPQ) yang telah menjamur di sudut-sudut desa untuk waktu yang lama, sekarang sulit untuk mempertahankan manajemen dan sumber daya. Sehingga saat ini di TPQ tahun 2000-an dikatakan sangat terbelakang karena sekolah-sekolah Islam dan lainnya baik di tingkat dasar maupun menengah telah menawarkan program pembelajaran tartil Al-Quran. Bahkan, ada juga sekolah yang memasukkan pembelajaran Alquran pada kurikulum reguler atau mata pelajaran. Secara metodologis, penelitian ini adalah penelitian kualitatif dengan menggunakan pendekatan Participatory Action Research. Pendekatan ini dimaksudkan untuk melihat, mendengar, dan sekaligus memahami gejala sosial yang ada pada mahasantri dan masyarakat sekitarnya. Dari pengamatan penulis secara langsung, dapat diketahui bahwa kemampuan siswa di YPPP an-Nuriyah bervariasi. Secara umum, mereka dapat dikatakan berada pada level menengah ke atas. Dengan kemiripan jenis kelamin, yaitu, semua siswa di pesantren ini adalah perempuan, pembelajaran Alquran bagi mereka lebih mudah dan lebih mendukung untuk pembacaan mereka.
\end{abstract}

Kata kunci: membaca, Al-Qur'an, santri.

\title{
Pendahuluan
}

Firman Allah Subhanahu wa Ta'ala diturunkan kepada Nabi Muhammad Shallallahu 'alaihi wa sallam melalui wasilahmalaikat Jibril as. serta diajarkan secara mutawatir adalah bukti validitas Al-Qur'an sebagai kalam yang suci dan dapat dijadikan pedoman sepanjang hayat bagi manusia. Fenomena pada saat ini, transfer informasi AlQur'an semakin melemah pada kalangan masyarakat. Baik berada pada kalangan menengah ke atas, maupun bawah. Hal ini terbukti jelas apabila kita meneropong fenomena tersebut di wilayah perkotaan.

Surabaya, adalah lokasi yang kongkrit menjadi objek pembahasan mengenai bagaimana perkembangan keilmuan Al-Qur'an didalamnya. Sebab, kesibukan masyarakat yang cukup tinggi, menyebabkan Al-Qur'an hanya dibahas pada taraf kaum agamawan atau santri ${ }^{1}$ saja. Bukti kongkrit lainnya, pada era 90-an, Taman Pendidikan Al-Qur'an (TPQ) yang sudah sejak dahulu menjamur di pojok-pojok kampung, saat ini maintenance baik manajemen maupun sumber dayanya sulit berkembang. Sehingga saat ini pada era 2000-an TPQ dikatakan sangat terbelakang karena sekolah-sekolah Islam maupun lainnya baik pada jenjang dasar maupun menengah sudah menawarkan program pembelajaran

\footnotetext{
${ }^{1}$ Santri adalah orang yang mencari dan belajar ilmu agama di sebuah tempat seperti pesantren, surau dll. Terkadang santri juga berdomisili ditempat belajarnya juga (boarding) untuk ngawula kepada pengasuh atau pemilik pesantren.
} 
tartīl al-Qur'ān.Bahkan, ada juga sekolah yang memasukkan pembelajaran Al-Qur'an pada kurikulum regular atau mata pelajaran.

Fenomena diatas, menyebabkan banyak inovator Islam yang mempromosikan AlQur'an lewat beberapa program kreatifnya. Misalkan, one day one juz, recording murottalQS. al-Rahmān, serta penulis juga sempat menemui kantor-kantor metode belajar Al-Qur'an cepat dan tepat atau yang lainnya. Misalnya Metode belajar Al-Qur'an Tilawati (Nurul falah), Qiro'ati, Ummi, dan yang baru adalah Bil Qolam. Semua yang hadir tersebut adalah kemasan pembelajaran Al-Qur'an yang dibilang modern pada kalangan masyarakat.

Selanjutnya, pada kalangan mahasiswa adalah masa transisi. Dimana ia pada mulanya berada pada jenjang anak-anak hingga remaja menuju dewasa awal. Dari fase ini, tidak jarang melihat kelompok mahasiswa lebih mengedepankan perkembangan keilmuannya sesuai dengan studi yang diprogramkan sejak awal. Contohnya, si fulan memilih program studinya di teknik industri, program studi manajemen pendidikan, dsb. Fakta tersebut, tidak bisa dinafikan bahwa ia hanya belajar dan mengembangkan keilmuannya pada program yang ia pilih untuk melangsungkan proses derajat akademiknya. Sehingga hanya segelintir mahasiswa yang mau belajar tentang Al-Qur'an. Seperti, program studi ilmu Al-Qur'an, Tafsir dan Hadis, bahkan jika ia ikut bergabung pada unit kegiatan mahasiswa yang bermuara pada Al-Qur' an².

Secara autentik,jika diperhatikan di wilayah perguruan tinggi UIN Sunan Ampel Surabaya, disebelah utara kampus, timur kampus hingga sebelah selatan kampus ${ }^{3}$, penulis melihat terdapat beberapa pesantren yang diperuntukkan mahasiswa. Sehingga pada perkembangannya, santri yang mengaji didalamnya sedang ia juga melaksanakan perkuliahannya, sering masyarakat menyebut mahasantri.

Pada programnya, secara umum pesantren tersebut menawarkan program ngaji dengan metode sorogan dan bandongan sebagaimana pondok pesantren salaf lainnya di beberapa daerah pedesaan. Namun, terdapat beberapa pesantren yang memberikan target kepada mahasantrinya dengan memberikan kurikulum tartîl al-Qur'ān dan atau program taḥfïz al-Qur'ān.

Objek pembahasan disini, penulis lebih memfokuskan pada satu pesantren yang didalamnya terdapat program pembelajaran Al-Qur'an sebagai pemantapannya. Bagaimana penulis juga berperan melakukan pendampingan dan pembinaan program tahsin al-Qur'ān dan pada jenjang lainnya juga dilaksanakan program tahfï̇ al-Qur'ān, hingga pada program di hari yang berbeda, terdapat program pelatihan membaca al-Qur'an bi al-Ghina, yang ketiga bentuk pembelajaran Al-Qur'an tersebut berada pada YPPP. AnNuriyah Surabaya.

\footnotetext{
${ }^{2}$ Ali Miftakhu Rosyad, “Al-Afkar, Journal for Islamic Studies URGENSI INOVASI PEMBELAJARAN DALAM PENDIDIKAN AGAMA ISLAM Al-Afkar, Journal for Islamic Studies THE URGENCY OF LEARNING INNOVATION ON ISLAMIC RELIGIOUS STUDY" 3, no. 1 (2019), https://doi.org/10.5281/zenodo.2546882.

${ }^{3}$ Terdapat beberapa pesantren yang menyediakan program mengaji dan diperuntukkan mahasiswa UIN Sunan Ampel Surabaya untuk berdomisili didalamnya. Seperti di sebelah utara kampus terdapat YPPP. An-Nuriyah, dan Ponpes Baitul Jannah. Sedangkan disebelah timur kampus terdapat Ponpes Mahasiswa An-Nur, Ponpes Darul Arqom, Ponpes Masykuriyah, Ponpes Jauharoh Darussalam, Yayasan Mitra Arofah, Ponpes Mahasiswa Al-Jihad. Dan di sebelah selatan kampus terdapat Ponpes Luhur Al-Husna, Ponpes Al-Jawi, Ponpes Nurul Falah. Dan banyak pesantren lainnya yang belum terdata. Hasil Observasi pada hari Selasa, 25 September 2018, 9.06 WIB di wilayah kelurahan Jemurwonosari, Wonocolo-Surabaya.
} 
Dari latar belakang diatas, penulis tertarik membahas bagaimana pendampingan dan atau pembinaan program pembelajaran Al-Qur'an di Yayasan Pondok Pesantren Putri An-Nuriyah Surabaya. Jadi penelitian ini difokuskan pada permasalahan bagaimanakah pelaksanaan program pembelajaran Al-Qur'an bagi mahasantri di YPPP. An-Nuriyah Surabaya, bagaimana kemampuan membaca Al-Qur'an mahasantri di sana dan faktor apa saja yang mendukung dan menghambat pelaksanaan program pembelajaran Al-Qur'an di YPPP. An-Nuriyah Surabaya.

\section{Tujuan Penelitian}

Penelitian ini bertujuan untuk membangun kecakapan mahasantri melalui pembelajaran Al-Qur' an di YPPP An-Nuriyah. Karena pada dasarnya, semua santri dikenal khalayak sebagai orang yang cakap dalam ilmu agama, terutama dalam membaca AlQur'an.

Penulis juga sebagai pengajar di YPPP An-Nuriyah merasa bertanggungjawab untuk membimbing mahasantri yang belajar di sini agar dapat memiliki kecakapan dalam membaca Al-Qur'an dengan baik dan benar sesuai kaidah ilmu tajwid dan dapatmenguasai keterampilan lainnya dalam bidang membaca Al-Qur'an.

\section{Kerangka Konseptual}

Dasar pembelajaran Al-Qur'an adalah Allah Subhanahu wa Ta'ala emnurunkan AlQur'an yang mulia kepada Nabi Muhammad Shallallahu 'alaihi wa sallam bagi alam semesta. Oleh sebab itu di dalam kehidupan beragam harus sesuai dengan ajaran AlQur'an karena Al-Qur'an merupakan pedoman dan pegangan hidup umat Islam. Untuk mengetahui ilmu-ilmu yang terkandung dalam Al-Qur'an, maka terlebih dahulu kita harus mengetahui dasar dan pengajaran Al-Qur'an.

Tujuan pembelajaran Al-Qur'an adalah hasil belajar yang diperoleh siswa setelah mengikuti pembelajaran Al-Qur'an. Di antara tujuan pengajaran Al-Qur'an adalah mampu membaca Al-Qur'an dengan baik dan benar, dan melatih anak-anak dalam membaca AlQur'an agar terbiasa mengucapkan kalimat-kalimat Arab sehingga ada kemudahan untuk menghafal Al-Qur'an.

Ibnu Khaldun sebagaimana ditutur kembali oleh As'ad Humam dkk, menunjukkan pada pentingnya mengajar dan menghafalkan Al-Qur'an pada anak-anak dan menjelaskan bahwa "pembelajaran Al-Qur'an itu merupakan pondasi pengajaran bagi seluruh kurikulum sebab Al-Qur'an merupakan salah satu syi'ar ad-dintyang menguatkan akidah dan mengokohkan keimanan."4

Rasulullah Shallallahu 'alaihi wa sallam juga memberikan perhatian yang sangat besar terhadap pendidikan Al-Qur'an khususnya untuk kalangan anak-anak. "Hal ini bertujuan untuk mengarahkan mereka untuk berkeyakinan bahwa Allah Subhanahu wa Ta'ala itu Tuhannya dan Al-Qur'an sebagai kalam-Nya agar ruh Al-Qur'an senantiasa tertanam pada jiwa mereka"s. Sehingga cahaya Al-Qur'an terpancar pada pikiran, pandangan indra serta dapat menerima akidah Al-Qur'an sejak dini yang tumbuh dan beranjak dewasa senantiasa mencintai Al-Qur'an, membacanya, menjalankan segala perintah dan menjauhi segala larangan-Nya.

\footnotetext{
${ }^{4}$ As'ad Human, “Dkk, 1991," Pedoman Pengelolaan Pengembangan Dan Pembinaan Membaca Dan Menulis Al-Qur'an, n.d.

${ }^{5}$ M Alawi Al-Maliki and Prinsip-prinsip Pendidikan Rasulullah, “Jakarta” (Gema Insani Press, 2002).
} 
Melalui pembelajaran Al-Qur'an diharapkan santri atau mahasantri dapat meningkatkan kemampuannya dalam membaca Al-Qur'an. Ada beberapa indikator kemampuan membaca Al-Qur'an dapat diuraikan sebagai berikut:

1. Kelancaran membaca Al-Qur'an. Maksudnya adalah membaca Al-Qur'an dengan fasih. bacaannya tidak tersangkut; tidak terputus; tidak tersendat; fasih; tidak tertunda-tunda.

2. Ketepatan membaca Al-Qur'an sesuai dengan kaidah ilmu tajwid. Sedangkan ilmu Tajwid adalah ilmu yang berfungsi untuk mengetahui hak dari masing-masing huruf dan sesuatu yang patut bagi masing-masing huruf tersebut berupa sifat-sifat huruf, bacaan panjang dan selain itu seperti tarqiq, tafhim dan sebagainya.

3. Kesesuaian membaca dengan makhārijul hurüf. Makhārijul hurüf adalah membaca huruf-huruf sesuai dengan tempat keluarnya huruf seperti tenggorokan, ditengah lidah, antara dua bibir dan lain-lain.

\section{Metode Penelitian yang Digunakan}

1. Secara metodologis, penelitian ini adalah penelitian kualitatif dengan menggunakan pendekatan Participatory Action Research (penelitian partisipasi). Pendekatan ini dimaksudkan untuk melihat, mendengar, sekaligus memahami gejala sosial yang ada di mahasantri dan masyarakat sekitar.

2. Dalam teknik PAR ini, cara pandnagn perencana atau pembuat program kegiatan memandang 'mahasantri' atau 'kelompok sasaran' sebagai 'subjek' bukan objek kegiatan. Sedangkan mahasantri atau kelompok sasaran menempatkan posisi sebagai insider (orang atau pihak yang berada di dalam kelompok sasaran dan turut aktif di dalam program kegiatan), bukan sebagai outsider (orang atau pihak yang berada di luar kelompok sasaran). Tujuan akhir atau muara dari dilakukannya kegiatan perencanaan, penelitian atau pengembangan dengan menggunakan metode PAR adalah upaya-upaya pemberdayaan mahasantri sebagai kelompok sasaran. Ciri khas sosial-budaya atau sosial-ekonomi yang dimiliki oleh kelompok mahasantri tertentu, perlu dikenali, dipahami serta diakomodasikan kebutuhan atau keinginanya, sehingga hasil perencanaan yang dilakukan dapat lebih adaptif dan akomodatif.

3. Menurut Bickman, Rifkin dan Shresta, ada beberapa indikator sebagai suatu basis untuk menjelaskan suatu metodologi yang berkembang untuk mengukur partisipasi masyarakat yang berfokus pada proses-proses daripada kegiatan. Indikator-indikator kualitatif dari partisipasi tersebut antara lain : adanya suatu kapasitas masyarakat yang tumbuh untuk mengorganisasi aksi, adanya keinginan untuk terlibat dalam pembuatan keputusan, dan adanya peningkatan kemampuan dari mereka yang berpartisipasi dalam mengubah keputusan menjadi aksi ${ }^{6}$.

4. Penilitian ini dilakukan di YTTP An-Nuriyah Wonocolo Surabaya. Fokus utama dalam penelitian ini adalah mahasantri yang berada di YTTP An-Nuriyah, yang mau tidak mau, langsung atau tidak langsung terkena dampak dari peningkatan kecakapan melalui pembelajaran Al-Qur'an, dan juga para pengajarnya.

5. Informan dalam penelitian ini adalah mahasantri YTTP An-Nuriyah yang dipilih secara acak. Sementara informan kunci adalah para pengajarnya. Dalam hal ini,

\footnotetext{
${ }^{6} \mathrm{Jim}$ Ife and Frank Tesoriero, "Community Development: Alternatif Pengembangan Masyarakat Di Era Globalisasi," Yogyakarta: Pustaka Pelajar, 2008, 265.
} 
informan dipandang sebagai pelaku utama dan penentu keputusan dalam keseluruhan proses penelitian ataupun proses aksi. Sementara itu, peran peneliti adalah membantu terjadinya perubahan tersebut. Adanya kepercayaan antara peneliti dan informan juga menjadi hal yang penting. Hal ini bertujuan agar dalam memberikan informasi, tidak ada rasa ketidakpercayaan informan terhadap peneliti. Oleh karena itu, teknik pengumpulan data dilakukan dengan cara pengamatan terlibat (participant observation), wawancara yang mendalam (indepth intreview) baik dengan mahasantri dan beberapa pengajar lainnya, yang bertujuan untuk menentukan need assesment dan membuat program yang menjadi kebutuhan mereka, serta studi dokumentasi. Selain itu, peneliti juga membutuhkan eksplorasi terhadap permasalahan yang diangkat.

\section{Hasil Penelitan dan Pembahasan \\ Program Pembelajaran Al-Qur'an \\ Pembinaan Tahsin Al-Qur'an}

Definisi dari pembinaan sendiri adalah usaha mendampingi peserta didik dalam mencapai tujuan pembelajaran. Adapun pembinaan sendiri lebih fokus pada prosesnya. Sebagaimana contoh, pendidik sedang membina peserta didiknya pada saat pembelajaran ${ }^{7}$.

Sedangkan tahsin adalah cara membaca Al-Qur'an dengan baik dan benardengan menggunakan kaidah-kaidah yang terdapat dalam ilmu tajwid, disamping memperbagus dan memperbaiki bacaan. Ali Muntaharmenjelaskan bahwa makna "tahsin" adalah senada dengan makna tajwidyakni perbaikan, penyempurnaan ${ }^{8}$.

Artinya, makna tahsin jauh lebih luas dari tajwid. hal ini dikarenakan di dalam tahsin, di samping mempergunakan kaidah-kaidah yang terdapat dalam ilmu tajwid, juga berusaha memperbagus dan memperindah bacaan dengan suara yang merdu. Dengan pembelajaran tahsin Al-Qur'an, maka di dalamnya sudah secara otomatis terdapat pembelajaran tajwid. Pembinaan tahsin adalah usaha pendampingan peserta didik dalam menyempurnakan kemampuannya dalam membaca al-Qur'an.

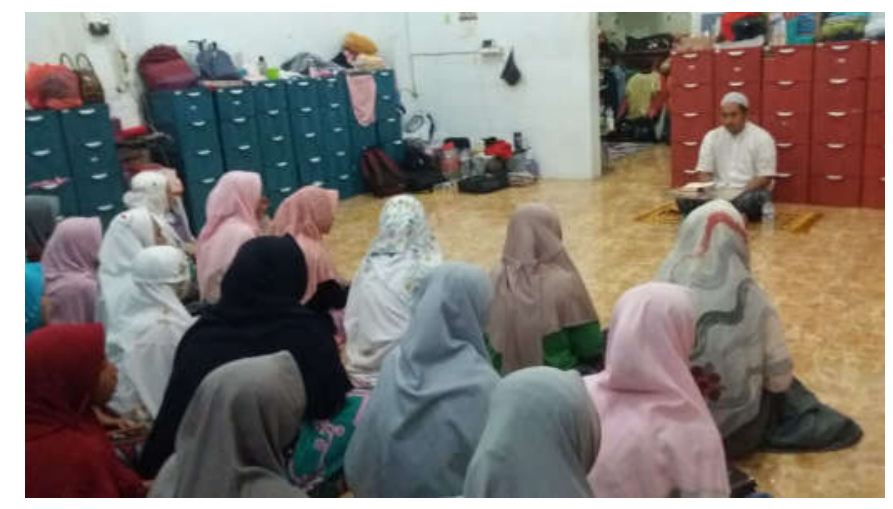

\footnotetext{
7 “Ali Miftakhu Rosyad IMPLEMENTASI NILAI-NILAI MULTIKULTURALISME MELALUI PEMBELAJARAN PENDIDIKAN AGAMA ISLAM THE IMPLEMENTATION OF MULTICULTURALISM VALUES THROUGH LEARNING OF ISLAMIC RELIGION EDUCATION" 5, no. 1 (2019), https://doi.org/10.5281/zenodo.2607388.

${ }^{8}$ Ali Mutahar, "Kamus Arab-Indonesia, Cet," Ke-1. Jakarta: PT. Mizan Publika, 2005.
} 
1) Metode yang digunakan

Metode yang digunakan dalam pembinaan Tahsin ini adalah menggunakan metode pengajaranBil Qolam karya KH. M. Bashori Alwi Murtadlo Singosari Malang. Metode pengajaran ini menggunakan metode Jibril yang dilakukan dengan beberapa tahapan, di antaranya adalah :

a) Tahqiq

Yaitu pembelajaran yang diawali dengan guru memberikan contoh bacaan yang sesuai dengan kaidah tajwid dan fashohah, santri mengikutinya, kemudian diadakan pengulangan-pengulangan minimal tiga kali dan sesuai kondisi santri dengan menggunakan khas tahqiq.

b) Talqin Waal-Ittiba'

Yaitu pembelajaran yang diawali dengan contoh bacaannya oleh guru, santri mengikutinya, kemudian diadakan pengulangan-pengulangan yang waktu dan cara penerapannya disesuaikan dengan kondisi santri dalam ruangan, jumlah tertentu, dan berbasis pada kemampuan santri dalam satu kelas.

c) Tartīl

Yaitu pembelajaran dengan membaca Al-Qur'an sesuai dengan kaidah tajwid dan fashohah yang benar dan baik. Dalam metode ini, digunakan lagu khas Bil Qolam atau lagu empat nada.

Dalam tahapan ini dilaksanakan dan diprakarsai oleh KH. M. Bashori Alwi, karena pada mengilhami daripada metode malaikat Jibril as menyampaikan AlQur'an yang sedang turun pada saat itu secara berulang-ulang.Disini penulis teringat statement dari Bahauddin Nursalim atau Gus Baha' yang mudah sapaannya. Ia sempat menungkapkan cerita tentang Nabi Yusuf as. Bahwasanya ciri-ciri nabi itu adalah Maksum. Yaitu dijaga daripada dosa. Namun terkadang Allah Swt mensetting hal tersebut agar Nabi juga pernah ditunjukkan unsur manusiawinya ${ }^{9}$.Hal ini sama saja pada saat nabi pada prosesnya menerima wahyu. Pada saat itu, nabi mencoba bersamaan ikut berucap pada saat malaikat Jibril membacakan ayat. Hal ini, Allah langsung menegurnya dengan menegurnya dengan menurunkan ayat لَ́yang pada intinya teguran tersebut menunjukkan unsur manusiawi Muhammad agar jangan ragu terhadap ayat yang telah diturunkan dan tergesa-gesa untuk menghafalkannya. Karena Allah ingin ia mendalami, mengilhami dan meneguhkan substansi daripada ayat yang diturunkan. Walaupun dalam penafsiran lain yang pernah dituturkan oleh Syaikh Yusri alMisri $^{11}$ menyatakan, teguran Allah Swt terhadap nabi Muhammad tersebut adalah sebuah uswah atau pembelajaran untuk ummatnya. Karena pada kaidahnya sendiri, sebelum Allah menurunkan Al-Qur'an kepada nabi Muhammad, padalauh alMahfuz Nabi sudah dihafalkan sendiri oleh Allah Swt pada penciptaannya. Melainkan teguran tersebut memiliki makna atau pesan, bahwasanya belajar AlQur'an haruslah diulang-ulang dan harus berprinsip pada karakter sabar. Yaitu ditempuh dalam jangka waktu yang lama.

\footnotetext{
${ }^{9}$ Bahauddin Nursalim, Cuplikan Ceramah Gus di Instagram, upload tanggal 8 Agustus 2019, pkl. 17.00 WIB

${ }^{10}$ QS. Al-Qiyamah 16

${ }^{11}$ Seorang guru besar Perguruan Tinggi Al-Azhar Mesir yang pada saat itu menuturkan dalam halaqah umum di Aula FDK Universitas Islam Negeri Sunan Ampel Surabaya.
} 
2) Pelaksanaan

Pelaksanaan pembinaan Tahsin yang di YPPP. An-Nuriyah ini secara langsung dibimbing oleh penulis setiap hari Ahad dan Jum'at setelah kegiatan sholat isya' berjama'ah.

\section{Pembinaan Qirō'ah bial-Taganni}

Qiro'ah adalah masdar (verbal noun) dari lafadzqara'a. Yang berarti bacaan. Adapun dalam istilah keilmuan ada beberapa definisi yaitu sebagai berikut:

1) Qiro'ah adalah salah satu cara membaca al-Qur'an yang dipilih oleh salah seorang imam ahli qiro'ah yang berbeda dengan cara orang lain dalam mengucapkan AlQur'an, sekalipun riwayat (sanad) dan tariqah (jalan)-nya sama.

2) Qiro'ah menurut Ibnu Aljazari adalah ilmu tentang cara menyampaikan (mengucapkan) kalimat-kalimat Al-Qur'an dan perbedaan-perbedaan yang dinisbatkan kepada orang yang menukilnya atau pendapat salah seorang imam dari para imam yang berbeda dengan yang lainnya, dalam hal pengucapan Al-Qur'an serta sepakatnya riwayat-riwayat mengenainya.

3) Qiro'ah adalah salah satu cara membaca Al-Qur'an yang selaras dengan kaidah bahasa arab, sanadnya muttawatir dan sesuai dengan salah satu dari beberapa mushaf Usmani $^{12}$.

Yang dimaksud dengan qiro'ah bit taghanni di sini adalah sebagaimana yang dimaksud dalam sabda Nabi Muhammad Shallallahu 'alaihi wa sallam yang artinya: "Bukan lah dari golongan kami, orang yang tidak taghanni (membaguskan suara) dalam membaca al-Qur'an." ${ }^{13}$ (HR. Bukhari). Maksudnya taghanni di sini adalah bukan menyanyikan tetapi memperindah suara saat membaca al-Qur'an. Dan termasuk bagian dari memperindah bacaan Al-Qur'an juga adalah membacanya dengan jahr (suara yang jelas) dan membacanya sesuai kaidah tajwid serta mahroj-nya.

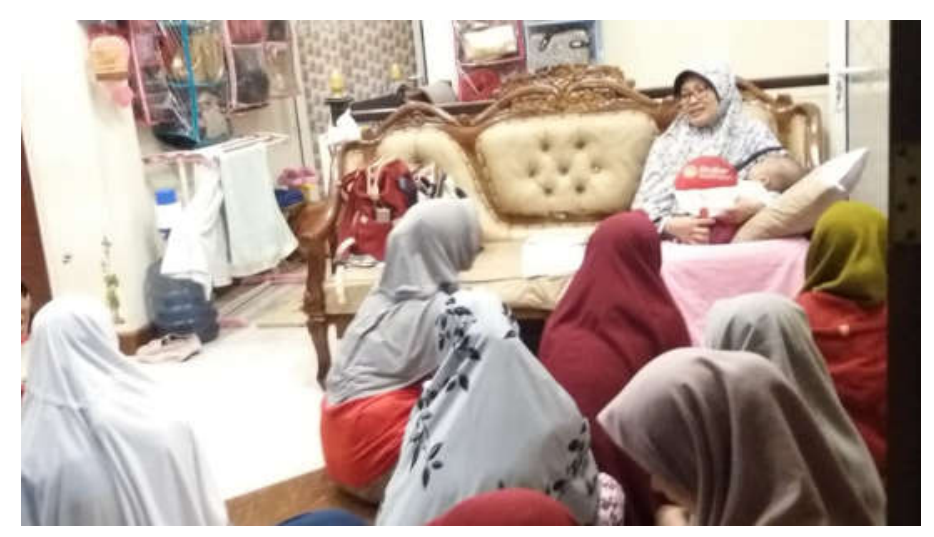

Pelaksanaanpembinaan Qiro'ah bit taghannidi YPPP. An-Nuriyahini setiap hari Senin dan dibimbing oleh ustadzah Syarifah. Dan kegiatan ini diikuti oleh semua mahasantri yang berada di pondok pesantren.

\footnotetext{
${ }^{12}$ Naqiyah Mukhtar, “Ulumul Qur'an,” Purwekerto: Buku Litera, 2013.

${ }^{13}$ Muhamad bin Ismail Al-Bukhori, "Shahih Al-Bukhori," Beirut: Darul Kutub, 1997.
} 


\section{Pembinaan Tahfiz Al-Qur'ān}

Tahfizberasal dari kata hafiza-yahfazu berarti menghafal, menjaga. Jadi Tahfiz alQur'ān bermakna menghafalkan al-Qur'an. Orang yang menghafal al-Qur' an berarti ia ikut juga menjaga keaslian dari al-Qur'an. Menghafal al-Qur'an merupakan suatu perbuatan yang mulia dan terpuji. Menurut Ahsin dalam menjelaskan tentang faedah menghafal alQur'an, salah satunya adalah orang yang hafal al-Qur'an akan mempunyai ketajaman ingatan dan kebersihan intuisi. Kemudian menjelaskan tentang bahtera ilmu al-Qur'an, disebutkan bahwa nilai-nilai al-Qurean yang terkandung di dalamnya akan menjadi motivator terhadap kreativitas pengembangan ilmu yang dikuasainya ${ }^{14}$.Maka dari itu, di YPPP an-Nuriyah diberikan pembelajaran Tahfïz al-Qur'anagar para mahasantri didik untuk memilikikecakapan dalam bidang menghafal al-Qur'an, sehingga mereka turut serta menjaga keaslian al-Qur'an.

1) Metode yang Digunakan

Metode yang digunakan dalam pembelajaran Tahfïz al-Qur'an di antaranya adalah :

a) Musyafahah, metode ini mensyaratkan adanya tatap muka langsung (face to face) antara santri dan ustadz/ustadzah.Maksudnya adalah memperagakan hafalan ayat al-Qur'an secara langsung di depan guru. Proses ini lebih dititikberatkan pada halhal yang terkait dengan ilmu tajwid, seperti makharijul huruf. Dan semua santri satu persatu harus menghafalkan al-Qur'an di depan ustaz/ustazah.

b) Talaqqi. Metode ini dilaksanakan bila santri akan memperdengarkan hafalannya secara langsung kepada ustaz/ustazah. Metode menekankan pada kefasihan bacaan.

c) Sima'an(sema'an), yaitu Saling memperdengarkan hafalan (bil-gaib) atau bacaan (bin-nazar) secara berpasangan (satu menghafal atau membaca, satu menyimak) dengan cara bergantian dalam kelompok juz. Kegiatan sema'an merupakan salah satu metode untuk tetap memelihara hafalan supaya tetap terjaga.

d) Takrir(deresan) yaitu para santri mengulang-ulang hafalan atau mensimakan hafalan yang sudah pernah dihafalkan kepada ustadz/ustadzah supaya hafalan yang pernah dihafal senantiasa terpelihara dan melancarkan hafalan yang pernah dihafal. Pada metode ini lebih dikhususkan untuk tingkat juz 'amma dan tingkat bil-gaib.

2) Pelaksanaan

Kegiatanpembelajaran Tahfïz al-Qur'an dilaksanakan setiap hari Jum'at dan dibimbing oleh Ustazah Atik Zubaidah al-Hafidzoh. Sementara itu, mahasantri yang berpartisipasi aktif dalam pembelajaran ini adalah mereka yang memiliki minat untuk menghafalkan al-Qur'an.

${ }^{14}$ Ahsin Al-Hafidz Wijaya, “Bimbingan Praktis Menghafal Al-Quran,” Jakarta: Bumi Aksara, 2005. 


\section{Kemampuan Mahasantri Membaca Al-Qur'an}

Menurut Poerwadarminta dalam Kamus Bahasa Indonesia, "mampu" berarti kuasa, sanggup melakukan sesuatu, sedangkan "kemampuan" berarti kesanggupan, untuk melakukan sesuatu ${ }^{15}$.Membaca adalah sebagaimana dikemukakan Hadgon dalam Tarigan adalah suatu proses yang dilakukan serta diperguna-kan oleh pembaca untuk memperoleh pesan yang hendak disampaikan oleh penulis melalui media kata-kata atau bahasa tulis ${ }^{16}$.

Sedangkanal-Qur'an menurut Quraish Shihab yang secara harfiah berarti "bacaan yang sempurna' ${ }^{17}$. Merupakan suatu nama pilihan Allah yang sungguh tepat, karena tiada satu bacaanpun sejak manusia mengenal tulis dapat menandingi al-Qur'an al-Karim, bacaan yang sempurna lagi mulia. Sehubungan dengan al-Qur'an keterkaitannya dengan Nabi Muhammad yang menerimanya, maka jelas menggunakan bahasa Arab, seperti yang disetir oleh Muhammad Fazlur Rahman bahwa: "Bahasa Arab sendiri, yang merupakan bahasa Alqur'an benar-benar merupakan bahasa yang sangat kaya, suatu kenyataan yang secara bulat disepakati penyelidik Arab, baik orang-orang Islam maupun non Islam. ${ }^{18}$

Kemampuan membaca al-Quran adalah merupakan hal yang penting dalam proses pembelajaran anak, karena hal ini adalah kemampuan dasar yang harus dimiliki oleh anak $^{19}$. Kemampuan membaca al-Quran hendaknya dimiliki anak sejak kecil. Bahkan pengajaran al-Qur'an sebaiknya terus diberikan kepada anak meskipun sudah berada di bangku kuliah.Kegiatan pembelajaran membaca Al-Qur'an harus memperhatikan kaidah syar'i. Kemampuan membaca Al-Qur'an adalah kecakapan membaca Al-Qur'an dengan bagus dan benar sesuai dengan tuntunan syari'at sebagaimana yang dijelaskan oleh ilmu tajwid. $^{20}$

Dari pengamatan penulis secara langsung, bisa diketahui bahwa kemampuan mahasantri di YPPP an-Nuriyah memangbervariasi. Secara umum, mereka bisa dikatakan dalam tingkatan medium ke atas. Dengan adanya kesamaan jenis kelamin, yaitu semua mahsantri di pesantren ini adalah perempuan, pembelajaran al-Qur'an untuk mereka lebih mudah dan lebih mendukung untuk diseragamkan bacaannya.

\section{Faktor Pendukung dan Penghambat}

Berkaitan dengan faktor-faktor pendukung dan penghambat dalam pelaksanaan pembelajaran Al-Qur'an ini sebagaimana yang penulis observasi secara langsung terlibat di dalamnya adalah bahwa segala bentuk kegiatan yang dilakukan oleh pondok pesantren termasuk pengembangan kurikulum tersebut tidak lepas dari faktor-faktor yang mempengaruhinya baik itu faktor yang mendukung maupun faktor yang menghambatnya.

Ketika faktor yang menghambat pengembangan kurikulum tersebuttelah diketahui oleh pondok pesantren sekalipun kecil sifat dan bentuknya, maka tidak boleh diangap ringan dan remeh, faktor-faktor tersebut segera dicarikan solusi terbaik dan logis untuk mengatasinya, jika tidak maka kegiatan yang dilakukan tidak dapat berjalan dengan baik bahkan bisa dikatakan sebagai awal kegagalan dan tidak mendapatkan keuntungan.

\footnotetext{
${ }^{15}$ W J S Poerwadarminta, "Kamus Umum Bahasa Indonesia, Jakarta: Balai Pustaka, 1991, Cet" (XII, n.d.).

${ }^{16}$ Tarigan Guntur Henry, “Membaca Sebagai Suatu Keterampilan Berbahasa," Bandung: Angkasa, 2008.

${ }^{17}$ M Quraish Shihab, “Wawasan Al-Qur'an, Bandung: PT," Mizan Pustaka, 2007.

${ }^{18}$ Muhammad Fazl-ur-Rahman Ansari, Konsepsi Masyarakat Islam Modern (Risalah, Bandung, 1983).

${ }^{19}$ Abdul Rauf and Abdul Aziz, “Anda Pun Bisa Menjadi Hafidz Al-Quran,” Markas Quran, Jakarta, 2012.

${ }^{20}$ Ahmad Annuri, "Panduan Tahsin Dan Tilawah Al-Quran \& Pembahasan Ilmu Tajwid," Bogor: Prim

Publishing, 2007.
} 
Di antara faktorpenghambatnya yang bisa penulis amati dari kegiatan-kegiatan pembelajaran tersebut adalah sebagai berikut:

a. Jumlah mahasantri dalam kelasmelebihi kapasitas ideal

Ukuran jumlah siswa yang ideal pembelajaran di dalam kelas adalah 15-20 anak. Sementara kelas pembinaan Tahsin, jumlah mahasantri sebanyak lebih dari 25. Sehingga pembelajaran Al-Qur'an yang dilaksanakan belum mencapai hasil yang maksimal. Jadi bisa dianggap baik dan ideal apabila dijadikan dua kelas dan hal itu jika memungkinkan.

b. Waktu belajar yang terbatas

Pertemuan dalam seminggu yang hanya sekali ini juga menjadi salah satu penghambat terhadap peningkatan kemampuan mahasantri dalam membaca AlQur'an. Karena dalam membaca Al-Qur'an, semakin jarang seseorang membacanya meskipun setelah mampu membacanya dengan lancar, maka ia akan mengalami ketidaklancaran dalam bacaannya. Apalagi hanya 2 atau 1 kali pertemuan dalam seminggu.

c. Jurnal guru dan daftar absensi mahasantri tidak tersedia

Untuk menunjang keberhasilan pembelajaran Al-Qur'an, seharusnya diperhatikan pula ketertiban administrasinya, seperti jurnal guru dan absensi siswa dalam hal ini adalah mahasantri YPPP An-Nuriyah yang mengikuti pembinaan AlQur'an. Jika memang tidak tertibkan administrasi pembelajarannya, maka dapat memberikan pengaruh yang kurang baik bagi keberlangsungan pembelajaran AlQur'an.

d. Target atau pencapaian pembelajaran dari pesantren belum dirumuskan

Salah satu penghambat keberhasilan pembelajaran Al-Qur'an di sini adalah belum adanya perumusan target pencapaian belajar dari pengurus pesantren. Jadi, langkah-langkah pembelajaran yang diambil oleh ustaz atau ustazah masih atas kehendak dan keinginannya sendiri. Sedangkan kita tahu bahwa kurikulum memegang peranan yang sangat penting demi keberhasilan pembelajaran, dalam hal ini adalah pembelajaran Al-Qur'an. Karena dengan pengembangan kurikulum yang baik, target dan pencapaian pembelajaran yang diinginkan jelas dan sudah melalui perencanaan yang baik, maka akan dapat memudahkan seorang guru atau ustaz melakukan pembelajaran dengan baik. Apabila pembelajaran berlangsung tanpa tahu dengan jelas target pencapaian belajar, maka pengajar juga akan mengalami kebingungan dan pembelajaran dilakukan sesuai kehendak mereka.

Adapun faktor pendukung yang bisa penulis amati dari kegiatan-kegiatan pembelajaran tersebut adalah sebagai berikut:

a. Suasana pembelajaran yang baik di pesantren

Suasana di pesantren memang sangat mendukung adanya pembelajaran ilmu agama. Di antaranya adalah pembelajaran Al-Qur'an. Seorang mahasantri harus memiliki kecakapan membaca Al-Qur'an. Suasana belajar di pondok pesantren baik sekali untuk belajar. Sehingga hal ini mendukung adanya pembiasaan membaca AlQur'an.

b. Jenis kelamin mahasantri yang homogen

Mahasantri yang homogen jenis kelaminnya yaitu perempuan dapat memudahkan untuk disamakan dan diseragamkan bacaannya baik secara mandiri maupun bersama. Hal ini dapat mendukung keberhasilan pelaksanaan pembinaan alQur'an di YPPP An-Nuriyah. 


\section{Simpulan}

Dari beberapa uraian tentangmembangun kecakapan mahasantri melalui pembelajaran al- Qur'an di YPPP An-NuriyahSurabayadapatpenulis simpulkan sebagai berikut:

1. Pelaksanaan Pembelajaran Al-Qur'an di YPPP An-Nuriyah

Ada tiga pembelajaran Al-Qur'an di YPPP An-Nuriyah, yaitu pembinaan Tahsin, Pembinaan Qiro'ah bit Taghanni, Pembinaan Tahfĩz Al-Qur'ān. Pembinaan

2. Kemampuan Mahasantri dalam Membaca Al-Qur'an

Dari pengamatan penulis secara langsung, bisa diketahui bahwa kemampuan mahasantri di YPPP an-Nuriyah memang bervariasi. Secara umum, mereka bisa dikatakan dalam tingkatan medium ke atas.

3. Faktor yang menghambat dan yang mendukung

Di antara faktor penghambat pelaksanaan pembelajaran Al-Qur'an di YPPP An-Nuriyah adalah jumlah mahasantri dalam kelas melebihi kapasitas ideal, waktu belajar yang terbatas, jurnal guru dan daftar absensi mahasantri tidak tersedia, target atau pencapaian pembelajaran dari pesantren belum dirumuskan.

Sedangkan faktor pendukung pelaksanaan pembelajaran ini adalah suasana pembelajaran yang baik di pesantren, dan jenis kelamin mahasantri yang homogen untuk kemudahan penseragaman bacaan.

\section{Daftar Pustaka}

Al-Bukhori, Muhamad bin Ismail. "Shahih Al-Bukhori." Beirut: Darul Kutub, 1997.

Al-Maliki, M Alawi, and Prinsip-prinsip Pendidikan Rasulullah. "Jakarta." Gema Insani Press, 2002.

Annuri, Ahmad. "Panduan Tahsin Dan Tilawah Al-Quran \& Pembahasan Ilmu Tajwid.” Bogor: Prim Publishing, 2007.

Ansari, Muhammad Fazl-ur-Rahman. Konsepsi Masyarakat Islam Modern. Risalah, Bandung, 1983.

Henry, Tarigan Guntur. "Membaca Sebagai Suatu Keterampilan Berbahasa." Bandung: Angkasa, 2008.

Human, As'ad. "Dkk, 1991." Pedoman Pengelolaan Pengembangan Dan Pembinaan Membaca Dan Menulis Al-Qur'an, n.d.

Ife, Jim, and Frank Tesoriero. "Community Development: Alternatif Pengembangan Masyarakat Di Era Globalisasi.” Yogyakarta: Pustaka Pelajar, 2008, 265.

Mukhtar, Naqiyah. "Ulumul Qur'an.” Purwekerto: Buku Litera, 2013.

Mutahar, Ali. "Kamus Arab-Indonesia, Cet." Ke-1. Jakarta: PT. Mizan Publika, 2005.

Ali Miftakhu Rosyad IMPLEMENTASI NILAI-NILAI MULTIKULTURALISME MELALUI PEMBELAJARAN PENDIDIKAN AGAMA ISLAM THE IMPLEMENTATION OF MULTICULTURALISM VALUES THROUGH LEARNING OF ISLAMIC RELIGION EDUCATION” 5, no. 1 (2019). https://doi.org/10.5281/zenodo.2607388.

Poerwadarminta, W J S. "Kamus Umum Bahasa Indonesia, Jakarta: Balai Pustaka, 1991, Cet." XII, n.d.

Rauf, Abdul, and Abdul Aziz. "Anda Pun Bisa Menjadi Hafidz Al-Quran.” Markas Quran, Jakarta, 2012. 
Rosyad, Ali Miftakhu. "Al-Afkar, Journal for Islamic Studies URGENSI INOVASI PEMBELAJARAN DALAM PENDIDIKAN AGAMA ISLAM Al-Afkar, Journal for Islamic Studies THE URGENCY OF LEARNING INNOVATION ON ISLAMIC RELIGIOUS STUDY" 3, no. 1 (2019). https://doi.org/10.5281/zenodo.2546882.

Shihab, M Quraish. "Wawasan Al-Qur'an, Bandung: PT.” Mizan Pustaka, 2007.

Wijaya, Ahsin Al-Hafidz. "Bimbingan Praktis Menghafal Al-Quran.” Jakarta: Bumi Aksara, 2005. 